\title{
CHAPTERS IN IOWA'S FINANCIAL HISTORY.
}

BY FRANK I. HERRIOTT, PH. D.

(Concluded from April.)

III.

One does not proceed far in a study of the finance of American states before he discovers the importance of constitutional limitations upon the powers of state legislatures. In the supreme statutes of a majority of the commonwealths the purposes, subjects and methods of taxation have been prescribed with greater or less detail. Above all these and paramount are the limitations of the constitution of the United States and the jurisdiction of the national government. These restrictions have perforce exercised a predominant influence in the financial history of the various states. They have proven rocks of offense and defense. The concurrent and conflicting jurisdictions of state and national governments have again and again put to naught the efforts of those who sought by legislative enactments to improve the methods of assessing and collecting the public revenues. In the constitutional provisions of the states the property rights of individuals, both private and corporate, have almost always found sure and sufficient protection from hostile class legislation and from most forms of adverse discriminations in the assessment of taxes even where the statutes invalidated obviously aimed at the promotion of the public interests.

Adopted, in most cases, forty and fifty years ago, such, constitutional limitations were drafted with conditions of industry in contemplation markedly different from those now confronting the law-maker. Their framers scarcely appreciated the nature and tendencies of modern industrial organization. It is not presumptuous to say that they did not anticipate the vast and momentous changes that we have witnessed in recent years. The course of financial legislation consequently has been materially 'different from what it 
would have been but for the interposition of the constitutional guarantees. Yet courts; while they have construed constitutions strictly, and have nullified numerous acts that violated their prohibitions, nevertheless have been considerably influenced by the drift of industry and experience and the pressure of public opinion.

The fact of predominant importance in the history of corporation taxes in Iowa is the provision in the constitution of 1857, section 2, article VIII, which requires that:

"The property of all corporations for pecuniary profit, shall" be subject to taxation the same as that of individuals."

The general purport of the section appears to be obvious. Yet analysis of its provisions in the light of experience since the adoption of the constitution shows that various constructions can be placed upon its terms. The constitutional debates, strangely enough, afford us little or no light as to the intent of the framers because of the fact that the section met with no opposition in the convention although from the proceedings we do obtain important information as to the interpretation warranted. The constitution of 1846 was silent upon the subject.

But it is easily seen from the discussions that took place upon those sections affecting banks and incorporations generally that there was considerable dissatisfaction with the burdens of local finance. Counties were heavily indebted on account of "Internal Improvements" and railroad construction.* And it is a fair presumption that companies that were promoting manufactures and railroads had been allowed greater or less exemptions from taxation as a part of the inducements offered them to invest their capital in the state and to assist in the upbuilding of ambitious communities. The excessive burdens which counties took upon themselves and the disappointments here and there over the material results naturally created the disposition to subject them to taxation. It was with a view to putting a stop to the inju-

* See Constitutional Debates, volume I, pp. 290-300, 307, 314, 330. 
dicious exemptions and relief of corporations from tax burdens and insuring equal and uniform taxation of corporations as with private persons, that the convention adopted that section of the constitution.*

Its provisions, prima facie require and guarantee the universal application of the General Property tax in the assessment of corporations. Property, real and personal, was no doubt assumed by the framers of the constitution to be the best general standard for measuring the ability of citizens and corporations to contribute to the support of government. Such was the general theory and practice of taxation in the State prior to that time.

But closer examination of the section shows that the language is not exclusive; it does not compel the legislature to bring all its enactments within a particular mode or kind of tax. There were in force at the time the constitutional convention was in session, sundry sorts of taxes on corporations, to which we have referred already, of which we may presume the convention took cognizance and did not deem undesirable. It is apparent that the terms of the section do not prohibit license taxes or the taxation of occupations, privileges or incomes if the legislature should see fit to impose them. Moreover, while the property of corporations must be subjected to taxation if the property of private citizens is so subject, there is no limitation whatever upon the power of the legislature to take various methods, however unlike they may be, for determining the value of corporate property subject to assessment; they may be arbitrary and in practical effect very inequitable yet they are permissible if the act is not local or special in character and its provisions apply uniformly to all persons within the class or industry defined by the statute.

These conclusions are not only warranted by the language of the constitution but they are the necessary inferences

- See observations of Justice Beck in City of Dubuque vs. The Illinois Central Bailroad Co., 39 Iowa, p. 69, and also those of Justice Cole, Ibid, pp. 97-98. 
from the very important fact that the convention refused to include in the section the limitation first proposed by the committee on incorporations, namely, that "their property shall be liable to taxation in the same manner as natural persons." So far as the writer knows the vital significance of that omission has been little considered, either in the opinions rendered by the courts or in the public discussions relating to the effect of the provision adopted.

The courts of Iowa have been called upon many times to pass on the meaning and define the scope of the provision of section 2, of article VIII. The earlier decisions, although the bench that handed them down was not always unanimous, have been continuously reaffirmed. So that while one finds in the first opinions here and there some-

* On January 26, 1857, Mr. James F. Wilson, delegate from Jefferson county, afterwards one of Iowa's distinguished representatives and senators at Washington, introduced a resolution in the convention instructing the committee on incorporations "to inquire into the expediency of amending the 8 th article of the constitution by
adding thereto the following section:

"Section -, That the property of corporations now existing, or hereafter created shall forever be subjected to tazation, the same as property of individuals." Constitutional Debates, p. 38.

This was agreed to and on January 30 th the following was reported and proposed as section 2:

"Corporations may sue and be sued, and their property shall be liable to taxation in the same manner as natural persons; and the liabilities, powers, privileges, and duties of stockholders in corporations may be fixed and detined by law, subject to the provisions hereof," Ibid, p. 96 .

This was amended on February 6th by isubstituting "the" for "their" before "properts" and after it inserting "of all corporations for pecuniary profit." (p. 289). On February 12th, Mr. Wilson moved the reference of the entire article to a select committee. This committee reported February 23d, recommending that all the first clause and all of the third beginning with "and the liabilities" be stricken out and the following substituted for the clause relative to this taxation of corporations:

"The property of all corporations for pecuniary profit, now existing or hereafter created, shall forever be subject to taxation, "the same as property of individuals." (p. 648).

When the report came up February 25th Mr. Wilson moved the adoption of the section as proposed by the select committee. His motion was lost by a vote of 7 to 11 (pp. 779-780). This matter was, however, reconsidered (p. 785). The section was again reported March 4th by the committes on revision as amended by the select committee (p. 1022). But the committee to which the entire constitution was re. ferred for critical examination prior to enrollment and signing cut out "now existing or hereafter created" and "forever" giving the present section (p. 1054).

In 1899 Attorney General Milton Remley in his argument on behalf of the State (pp. 7-8) in the case of The Hawkeye Ins. Co. vs. French, pointed out the omission just noted and insisted upon its vital importance in construing the section. 
what of confusion in the lines of argument there has long been complete agreement as to the force and effect of the provisions of the section.

The very wide range of the power of the legislature with respect to methods for fixing or arriving at the assessable value of corporate property was clearly announced in a decision given by the court in 1869 . In 1868, the legislature enacted the law, already noted, whereby express and tele-. graph companies were assessed on forty per cent of their receipts. It was resisted on the ground that it was arbitrary in the extreme, that assessors did not assess the real value of the company's property or so much as attempt to do so as in the case of individual property, and further that it was in effect a tax on income and not a tax on property. Justice Cole, speaking for the court, in the U. S. Express Co. vs. Ellyson, observed:

It must be borne in mind that we have not in this State, as they have in Wisconsin, a constitutional provision declaring that the "rule of taxation shall be uniform." Nor, as in Ohio declaring "that laws shall be passed taxing, by uniform rule, all moneys, credits, investments in bonds, stooks, joint stock companies, or otherwise; also all real and personal property according to its true value in money."

A careful reading of the law in controversy must discover to every candid mind, that it simply subjects the property of express and telegraph companies to taxation, and prescribes a rule (arbitrary, or even unreasonable it may be) whereby the amount of that property shall be ascertained, to-wit: forty per cent of the gross receipts within the particular taxing. district, from its business during the preceding year.

The court refuses to consider the objection that the tax is upon income, holding "in our view of the law, as above expressed, it only imposes a tax upon property, and prescribes the means of ascertaining the amount of it-the method of assessing it."*

There united in that opinion Justices John F. Dillon, Geo. G. Wright, and James E. Beck-the strongest bench Iowa ever has had. Their holding with respect to the power of the general assembly to take various methods for assessment has been reaffirmed many times, notably in $\mathrm{Du}$ -

* 28 Iowa, pp. 377, 379, 380. 
buque vs. C. D. \& M. R. Co. (47 Iowa 196); Central Ia. R. Co. vs. Bd. of Supervisors (67-199); Primghar State Bank vs. Rerick (96-238); and Hawkeye Ins. Co. vs. French (109-585). In the latter case, decided in 1899, the language of Justice Deemer is explicit upon this point:

We are not to be understood as questioning the right of the legislature to adopt different methods for ascertaining values, adapted to the various peculiarities of the property, or its right to fix the situs of property, both real and personal, although, in the exercise of such rights, inequalities must, of necessity; result.

In the Ellyson case the court plainly declared that it was within the power of the general assembly not only to prescribe the conditions and methods of assessment for taxation but also to predetermine value "regardless of the fluctuations of circumstances that between buyer and seller in the market influence prices and values. It is not necessary under that decision that assessors should exercise their individual judgment and be given discretion to adjust valuations to such fluctuations.

The extent to which uniformity of taxation is enjoined by the constitution, the real meaning of uniformity and the latitude allowed the legislature in imposing other taxes than the general property tax were outlined by the court in 1870 in the case of Warren vs. Henly (31-31), Justice Beck in the course of his opinion, saying:

They [taxes] must be uniform. By this I understand that they must not be imposed alone, nor unequally, upon particular individuals or classes. This rule, however, I understand, is applioable generally to the principle or plan of taxation, and not to speciflc or particular taxes. It means that all individuals and all classes shall be uniformly taxed. It does not mean that certain particular taxes, as income taxes, licenses, specific taxes apon certain property used as instruments of profit, or articles of luxury, shall be prohibited. These are not uniform in one sense; that is, all do not pay them. They are and must be uniform in another sense; that is, all possessing particular incomes, exercising certain business, and owning the specified property, must be subject to the same tax. They are again not uniform in another sense, for under them the burden of taxation is not uniformly borne. All incomes may' not be taxed; those of a certain amount may be exempt; licenses may not be imposed upon the exeroise 
of all branches of business, and all artioles of property ased for prott or luxury may not be epeoifically taxed. The rule means that all individuals and all classes must contribute uniformly with like individaals and like classes to the burden of taxation. The manner of imposing this burden must, of necessity, be left to the discretion of the legislative branch of the govern. ment. That a tax or a system of taxation may not bear equally upon all, when weighed in the nicest balance of equity and justice, is no reason for holding that it conflicts with the fundamental and essential rule under consideration.*

In 1899 in the case of The Scottish Union and National Insurance Company vs. John Herriott, Treasurer of State, in holding valid the differential state tax on the premium income of foreign insurance companies doing business in Iowa, the court, while conceding that the statute might be subject to attack if it assumed to give the state treasury exclusively the proceeds of a tax on the property of such com: panies, held very decidedly that any kind or degree of tax on business, or on the privileges of engaging in business in the state was permissible under Iowa's constitution. The court further held that it is not required that the tax should be "uniform" in the sense that it should be universally assessed at the same time upon all lines of business, or upon all business rights or privileges. It is competent for the legislature to discriminate or to classify and impose business or license taxes upon such lines of industry or privileges as public policy may indicate to be desirable.t

IV.

It is when we come to study the development of state and local taxation in Iowa that we discover the far-reaching importance of the second section of article VIII. In many respects the chief controversies that have been waged in the courts-at any rate those in which the tax-payers took the keenest interest-have related to its effect upon the rights or powers of minor civil divisions in the assessment and taxation of the property of corporations within the local taxing

* See 31 Iowa, pp. 39-40.

† 109 Iowa, ค. 613 . 
areas. In the earlier laws, as we have seen, the legislature to a greater or less extent denied, at least apparently intended to deny, to cities, towns and townships the right to levy taxes upon certain classes of corporations, reserving such right, or the benefit of the taxes, to the State entirely, or to the State and counties jointly. This restriction on local taxation in a short time became a cause of complaint, particularly in the older and larger cities in the eastern portion of the State. Dubuque, Clinton, Davenport, Muscatine and Burlington became, after 1860, centers of railroad traffic. They soon possessed large and"valuable railroad properties, which were entitled to police and fire protection as was the property of private citizens. The law of 1862 which exempted railroads from local assessment was therefore felt by local taxpayers to be unjust.

Despite the prohibition the local authorities of Davenport ignored its provisions and proceeded to assess the personal as well as the real property of the railroad within their jurisdiction. They contended that the act providing for a tax on the gross earnings of railroads related simply to county and State taxes and did not abrogate the prior statutory provisions authorizing cities to levy on all properties within their bounds; and further that it was unconstitutional, as in a case brought by the city in 1859 in an attempt to assess non-resident holders of mortgage bonds given by the Mississippi \& Missouri Railroad the supreme court declared that the constitutional guarantee required that the burden of taxation should be "borne equally by all"; the property of one is liable to the same extent as that of another; of corporations like that of individuals. *

The city was successful in the lower court, and in the supreme court, by reason of an equal division of the bench, the decision was affirmed without the issue being clearly decided. The bearing of section 2, article VIII, was only incidentally noted but not considered. $\dagger$ In 1869 the court,

* The City of Davenport vs. The M. \& M. R. R. Co. (12-539),

† The City of Davenport vs. The M. \& M. R. R. Co. (16-348). 
reaffirmed, but again with dissent, the right of cities to tax corporate properties notwithstanding the companies had paid the tax on their gross earnings to the State; the court, however, avoided passing upon the constitutional question.* It was not until 1874 that the effect of the provision in the matter of State versus local taxation was announced in the case of the City of Davenport vs. The C., R. I.\& P.R.R. Co. (38-633). The legislature in enacting the law of 1872 providing for the present method of assessing railroads had exempted them from the payment of all local levies assessed previous to the passage of the act. $\dagger$ That exemption was resisted by the cities on the ground that the constitution required that corporations should pay the same taxes upon their property that private individuals sustained upon their property. The court declared (with dissent however), that "each shall be taxed for the same objects, and in the same degree, so that individuals shall not be required to pay any taxes on their property which are not also assessed and. laid upon the property of corporations of the class named, nor in any greater proportion." (38-644).

In another case decided at the same term, the City of Dubuque vs. The Illinois Central R. R. (39-97), Justice Cole dissented from this view (as he had in each preceding case), holding that "the manifest purpose and intent of the section is, to place the property of corporations just like the property of individuals, completely within the legislative power for the purposes of taxation; so that the legislature could use the same authority and discretion in the enactment of laws for the taxation of the property of corporations, as it. could use in the enactment of laws for the taxation of the property of individuals. '. . $\therefore$ The sole practical effect. of the section is, to clothe the legislature with the authority to subject to taxation the property of corporations, although

- The Dunleith \& Dubaque Bridge Co. v8. the City of Dubuque (32-427).

† Laws of 1872, chapter 26, section 9.

Vor. $\mathbf{v}-28$. 
by the terms of their charters previously granted, they were exempted from taxation."

In other words under the majority opinion exclusive State taxes were held to be contrary to the constitution. The same burdens, the full weight of each and all tax levies ordered in every community, must fall upon the property of all corporations within the taxing district that fall upon manufacturers, merchants or house-owners within the same district. It is not competent for the legislature to deny to local authorities the power to compel resident corporations to contribute equally with private citizens to the support of local government according to the value of their property. The rulings in these cases were reaffirmed in 1899 in the case of The Hawkeye Ins. Co. vs. French (109-585), when the State tax on domestic insurance companies was pronounced invalid.

The same question from a somewhat different point of view was considered in another leading case arising under the law of 1872. By that act the value of a railroad was to be ascertained and fixed by the census board, since known as the executive council. The officers of the roads were required to report the value of all the miscellaneous properties of their roads, as well as the value of their road bed and rolling stock, to the State board. The council was then required to place a value on the property. But the value so fixed was not certified back to the local tax officers of each county along the line of the road in proportion to the actual or reported value of the property within each local taxing district. The assessed value of all the properties of the entire road in the State was "lumped" and then parceled or "spread out" through urban and rural districts equally according to their single track mileage: Under this method the great values found in the cities were extended to the country districts and the taxable properties of the cities were by so much reduced. This arbitrary apportionment of the railroad values of the State was forthwith contested by the cities on the ground that in reducing their valuations within the corporate limits 
railroads were relieved at the expense of private tax-payers. The court was much divided. The majority, however, sustained the law, following the ruling in $U$.S. Express vs. Ellyson (28-370): The legislature had determined the situs of railway property and prescribed the method for its valuation and upon the assessment all local taxes were to be levied. There was, in their opinion, no denial of the right to tax railroads locally. The fact that there was a distribution of values, whereby the rural districts gained at the expense of the urban communities was an inequity that was an unavoidable incident of the method adopted, but it did not render the law invalid.

One experiences no little perplexity in following the tortuous courses of judicial opinion in construing the constitutional provision governing the taxation of corporations in Iowa. And the more one studies the several decisions and the circumstances of each case, the more the conviction grows that the court gave heed more to the inequalities locally experienced under the statutes in controversy, against which there was great popular protest, than to what was a fair and reasonable construction of the law and the constitution. This seemed to have been particularly true of all the cases involving the law of 1872, except the last. The court has derived two constructions from language that one may fairly presume meant one of two things but not both. The vital clause of section 2, article VIII, "Shall be subject to taxation the -same as that of individuals," has been held to mean sameness of tax burdens and variety in methods of assessment, a construction that seems arbitrary. If the words, the same, on which the whole matter turns, do not mean and do not enjoin that precisely the same methods shall be pursued in assessing corporate property and in collecting the taxes levied that are authorized in the taxation of individuals, it is difficult to perceive wherein they command that precisely the same bur-dens shall fall upon corporate and private property. For -either conclusion the premises are the same and it would 
seem that they should compel the same construction, be it as to methods of taxation or as to the benefits or results. The nature of the changes made in the section in the constitutional convention, and the fact that during the debates there was no sign of opposition to the method of taxing railroads and insurance companies then pursued, tend strongly to justify the conclusion of Justice Cole and the contention of Attorney General Remley, that the intent of the constitutional convention was simply to bring corporations within legislative authority and prohibit their exemption from taxation; that it is competent for the legislature to determine not only whether they shall be taxed in one way or another, but whether the State or the local taxing power, or both, shall obtain the proceeds of the taxes assessed. If the method adopted proves unsatisfactory in practice, whether because the taxes collected are insufficient, or because they are inequitably assessed, the remedy is within legislative discretion; the rate of tax can be increased or the method and machinery for assessment improved and made more effective.

The practical consequences flowing from the construction placed upon the constitution in the matter of State and local taxation have been of the utmost importance in the history of the State. It is not an exaggeration to say that no other one thing has been so potent in obstructing improvement in Iowa's revenue laws as the view of the court just outlined. It has been an effectual barrier to the divorcement of State and local sources of revenue. When we consider the very serious and constantly recurring inequalities in the burdens borne by the counties with respect to State taxes due to the constant efforts of each county to escape a part of its share by under-valuation in local assessments, it may well be doubted if the cities and townships did not achieve a costly victory in the decisions nullifying the exclusive State taxes on corporations. 
V.

In several other respects the courts have played a prominent part in the history of the development of corporation taxes in Iowa. The first act lerying a tax on the capital stock of national banks was declared void because the tax was assessed against securities of the federal government exempt from taxation, ${ }^{*}$ and the legislature was forced, in 1868, to follow the course of New York and other states and assess banks upon the shares of their capital stock. $\dagger$ Numerous attempts to tax United States bonds have since been defeated by the courts. With the exception of the cases affecting the construction of section 2 of article VIII the most important line of decisions relate to the taxability of corporate property, shares of stock and surplus funds, and to the deduction of corporate and individual indebtedness in the assessment of corporations and shareholders.

In the earlier decisions of the court strong disapproval was expressed respecting the simultaneous taxation of both the property of corporations and the shares of capital stock, on the ground that it was double taxation. In Tallman vs. Treasurer of Butler Co., it was held that the tax on the shares of stock of railroads was the only tax assessable on such property under the code of 1851 , and all attempts to tax the real estate were defeated, $\downarrow$ and in the case of the United States Express Company vs. Ellyson, while not denying the possible legality of double taxation, the court observed that it is "so unjust as naturally to excite the disfavor of both courts and legislators." $\|$ But in 1882 in Cook vs. The City of Burlington, the court expressly held that "duplicate taxation" was not only not "in excess of the legislative power" but that no injustice was necessarily inflicted on corporate undertakings when both the property of the companies and the shares of

\footnotetext{
* See Hubbard v8. Board of Supervisors of Johnson Co., 23 Iowa p. 130.

† Laws of Iowa, 1868, chapter 153; and the case of Morseman vs. Younkin. 27 Iowa p. 350.

$\ddagger$ See 12 Iowa, p. 531 .

II See 28 Iowa, p. 378.
} 
stock were made liable for taxation.* The corporation and the shareholders are suparate and distinct persons, just as are mortgagor and mortgagee, and the value of their several holdings depends upon clearly defined and different foundations. Any other view, it was declared, "would open the door into a sea of troubles in the administration of the revenue laws of the State.".

As regards the nature of shares of stock in considering their liability for assessment the supreme court has reversed its first rulings. In 1887 in Bridgman vs. The City of Keo$k u k, \uparrow$ shares of stock were declared to be not "credits" in the hands of holders, or "debts" owing by the corporation to the 'shareholders, but they were classifiable as ordinary property; and owners were denied the right to deduct indebtedness therefrom in making their returns to the assessors. The year following in the notable case of the Equitable Life Insurance Co. vs. The Board of Equalization of Des Moines, the court squarely held that shares of stock represented a. debt of the company to its shareholders which could be deducted from the amount of the company's moneys and credits. And the value of the shares which may be deducted, represent the total assets of a company, not only the capital stock but the surplus, undivided profits, and reserve funds. In the case of insurance companies policies of insurance in force were further declared to be obligations that came within the deductible debts. $\$$ The effect of the court's decision in this case was to relieve Iowa domestic or local insurance companies from taxation; and they enjoyed immunity from tax burdens until the recodification of 1897 . In 1892 the supreme court went a step farther and held in the case of the First National Bank of Albia vs. The City Council of Albia, that shares of stock in the hands of holders were

* See 59 Iowa, p. 251.

+ Bee 72 Iowa, p. 42.

† See 74 Iowa, p. 178. See also Campbell v8. Centerville, 69 Iowa, p. 439 ; Iowa State Savings Bank vs. Burlington, 98,Iowa, p. 737 ; and Ottumwa Savings Bank vs, Ottamwa, 95 lowa, p. 176. 
"credits" from which "debts" owing by the holder could be deducted by him in making his returns to the assessor.*

\section{VI.}

The history of corporation taxes in Iowa to be complete should indicate not only the course of actual legislation and the drift of judicial decisions but exbibit the growth of public discussion and opinion which, as a rule, gives impetus to the enactment of laws and influences more or less the views of courts. It is almost, if not fully, as important to know the character and extent of such popular discussion, the theories or views most current and most urgently pressed on legislative consideration; even if the advocates failed to secure the favor of the predominant party, as it is to know the measures finally agreed upon. Laws are so frequently compromises between conflicting forces or interests, or mere makeshifts passed to meet a political exigency, that unless we know the nature of public discussion prior to statutory enactments we will not always appreciate their real historical significance.

We find two well-marked periods in the development of corporation taxes in Iowa within which the subject aroused widespread public interest, the workings of the existing laws were subjected to much scrutiny and various reforms were advocated with considerable emphasis. The first period ranges from 1862 to 1873 . The second begins about 1890 and continues down to 1902 . The two periods differed somewhat with respect to the character of the public discussion prevailing in each.

During the first period there was, as compared with the second, comparatively little consideration of the merits of the various methods of taxing corporations. In $1862 \mathrm{it} \mathrm{was}$ proposed that railroads should be taxed locally as otner property, $\nmid$ but the law taxing them on their gross earnings was

* Seo 86 Iowa, p. 28.

$\dagger$ See bill introduced by Mr. T. H. Stanton described in editorial in Iowa State Register, Feb. 12, 1862. 
adopted. This law was simply the basis or starting point for a more animated discussion. There was soon apparent, particularly in the eastern counties, a general feeling that railroads were not contributing as much revenue as other classes of property.* The reservation to the State and county treasuries of the taxes paid by railroads, as we have seen, produced great complaint. The demand that railroad and other corporate property be subjected to the same local burdens that private citizens were was steadily and unceasingly pressed. This demand was urged the more strongly in some of the counties because of the heavy burdens of indebtedness which they had assumed to aid in the construction of the railroads which, in many cases, had not been completed as promised. The complaints on this score were so serious that repudiation was attempted in several instances and an appeal for relief was made to the legislature. In the legislative debates in 1870 the statute denying cities the right to tax railroads was roundly denounced. $\dagger$ The decisions of the supreme court, outlined in a preceding section, forced the subject upon the legislature.

The local taxation of corporations thus became the main objective of public discussion. From the nature of the local contests and the drift of judicial opinion the general property tax was advocated as a matter of course. The railroads owned large amounts of real estate in the cities. Private citizens were taxed on their real and personal property and the logic of the situation seemed to require that corporations be likewise taxed on their shops, machinery, depots and yards. The relative advantages of the different methods of corporate taxation were discussed to some extent in the debates in 1870 but generally speaking the matter of chief interest was the local taxation of the property of such corporations rather than the manner in which such property should be valued for the purposes of taxation. $\neq$ There was a serious

* See report of Treasurer of State, 1870, p. 13.

$\dagger$ See Des Moines Bulletin, Legislative Supplement, No. 30, for March 7, 1870 .

I Ibid, Nos, 37, 43, 48, 51-54. 
effort made to secure the adoption of the Illinois law of 1853 under which the property of railroads was assessed by local assessors.* The result of the agitation was the passage of the act imposing a graduated tax on the gross earnings of the railroads. $\dagger$

But the adjustment was not very satisfactory, and public interest continued. The decision of the supreme court in the Dunleith and Dubuque Bridge Co. case, in which the right of cities to tax corporations, regardless of legislative prohibition, was conceded, precipitated matters. The railroad managers were forced to urge legislation to protect their properties from what may be deemed excessive local assessments. Valuation of their property was admitted but they urged assessments by a state board, uniformity in valuation, and the equal distribution of their valuation on a mileage basis. This was vigorously opposed by the representatives of the cities.|| But the railroads enlisted the support of the representatives of the agricultural interests because the law proposed by them apportioned to the rural townships values actually in city areas. Feeling was evidently intense for in the legal battle which followed the attorneys for the cities boldly and bluntly charged that the law was passed by the influence of a corrupt lobby, $\$$ and Judge Beck in his dissenting opinion gives countenance to the charges. ๆ

In the first period one occasionally finds evidence that some consideration was given the matter of the incidence of taxes placed on railroads. When the first discussion arose in 1862 the opponents of "radical" legislation dwelt on the unwisdom of placing heavy burdens on railroads then in the process of building extensions for the reason that their taxes would by so much retard the completion or extension

* Ibid, No. 37, and Iowa Senate Journal, 1870, pp. 160, 224.

† Laws of 1870, chapter 106.

$\ddagger$ See argument of Mr. Thos. Withrow on rehearing in Dubuque v8. C., D. \& M. R. Co. (Abstracts and Arguments, vol. 91).

|l See protest of John H. Gear and others, House Journal, March 13, 1872, pp. 424-s. 8 Seo petition for rehearing in Dubuque ve. C., D. \& M. B. Co.

Tा 47 Iowa, p. 204. 
of the roads.* Later when the regulation of traffic rates became such a vital issue it was frequently urged that unless the legislature superimposed definite tariff schedules it would be fruitless to enact a tax measure as the railroads would simply increase their freight and passenger rates and recoup themselves for the taxes they might be compelled to pay. $\dagger$

Although the general property tax was adopted for railroads in 1872 we find in the first inaugural address of Governor Cyrus C. Carpenter a noteworthy recommendation that entitles him to more than honorable mention in the financial history of the State. He urged the taxation of the "franchise" as the most satisfactory basis for determining the just taxable valuation of railroads. His is the first state paper in which we find any other method of assessment than the general property tax suggested. His language is worth quoting. After pointing out that it is not feasible to adapt the "same mode of assessment" to railroads that is "applied to the assessment of private property," he says: "The value of "a railroad is evidently not in its right of way, embankments, "masonry, bridges, ties, iron, machinery, locomotives, cars, "buildings, \&c., \&c., but in the essential franchise, and the "value of this franchise is dependent upon dividends." $\neq$ The legislature adopted Governor Carpenter's recommendation relative to the method of assessing railroads but not his suggestion urging that the value of the franchise be taken as the basis for valuation.

Between 1872 and the beginning of what is here designated as the second period, beginning about 1890 , there were a number of official recommendations that should be noted as sort of landmarks in the progress of public opinion.

In $1875 \mathrm{Mr}$. Buren R. Sherman in his report as auditor of state called attention to the escape from taxation of telegraph, telephone, fast freight, and Pullman car companies,

* See editorial Iowa State Register, Feb. 12, 1862. 1872 .

† Ibid, Feb. 17, 1872; also, Iowa Homestead and Western Farm Journal, Feb. 23, \$ See Governor Carpenter's inaugaral, 1872, p. 20. 
and the impracticability of their taxation by local authorities, and he advocated convincingly the supervision of their assessment by the State board.* His suggestions were commended by Governor C. C. Carpenter in $1876, \dagger$ and by Governor J. G. Newbold in $1878 \ddagger$ with the effect that the legislature, as already pointed out, placed the assessment of such companies under the State's executive council. Later, in 1886, when Mr. Sherman became governor, he strongly urged the entire divorcement of State and local sources of taxation and the support of the State government from corporation taxes, chiefly from railroads.

The first suggestion of the advisability of separating State and local sources of revenue, so far as the writer can discover, was made by Mr. John H. Ames in 1878, in a paper in The Western Jurist (Vol. XII, p. 152), published at Des Moines, entitled "The Taxation of Real Property and Corporations." $\mathrm{He}$ advocated the plan adopted in Pennsylvania as the most effective method of abolishing the evils of undervaluation. In the discussion preceding the appointment of the revenue commission in $1892 \mathrm{~L}$ this plan was again urged.\$

In 1887 Governor William Larrabee, as a member of the executive council, urged that body to adopt net earnings as the basis for determining the aggregate valuation of the railroads of the State, proposing that the earnings be capitalized at the current interest rate. His resolution was not adopted. Its introduction, however, led to an increase in the assessed value of such property. $T$

In the senate that year Senator C. H. Gatch of Des Moines introduced a measure providing for a general "franchise" tax on corporations.** The tax he proposed was to be

\footnotetext{
* See report of auditor of state, 1875, p. 7 ; also report for 1877, p. 8.

† See Gov. C. C. Carpenter's message, 1876, p. 4.

¥ Gov. J. G. Newbold's message, 1878, p. 6.

|| See Gov. Buren R. Sherman's message, 1886, pp. 4-5.

8 See article on "Tax Reform," Homestead, vol. 38, p. 121, Feb. 5, 1892.

Tा See Record of Proceedings of the executive council, March 7, 1887.

- See senate flle 20, session 1888.
} 
a tax on the capital of a company collectible only when it was organized, or applied for a renewal of its articles of incorporation or amended them. It was not such a tax as Gov. Carpenter advocated in 1872 , or as was recently. adopted in New York on the recommendation of Governor Roosevelt. In most respects Senator Gatch's franchise tax was simply an. incorporation fee or license tax: The measure encountered strenuous opposition and failed to pass not only in 1888 but again in 1890 and again in 1892.*

Meantime public discussion of the problem of taxation was increasing. It culminated in the appointment of the revenue commission in 1892. Then began the agitation for reform in corporate taxation that has been more or less persistent from that time down to the present. The methods of raising revenue then in force were generally conceded to be "burdensome, unequal and unfair" and there was a vigorous demand for some system of taxation that would command "the respect and confidence of the people." $\dagger$ Public discussion has been widespread and for the most part enlightening. Methods have been presented and considered with considerable vigor in official papers and in the press of the State. Questions of the incidence and industrial effect of different methods of assessment have been debated as well as their fiscal benefits or efficiency as financial measures. Interest in these matters has been at times very keen, influencing the drift of political opinion and party action.

The revenue commission in their report in 1893 recommended the franchise tax advocated by Senator Gatch and also a general corporation tax for ordinary business corporations. The method of assessment urged was their valuation upon the basis of the market value of their shares of stock and the collection of the taxes levied through the corporations. They recommended the taxation of telegraph, tele-

In 1896 a law was passed providing for the collection of such a fee. See chapter 98, laws 1896.

† Preamble of the act creating the revenue commission, chapter 72 , laws 24 th G. $A$.

$¥$ See report of revenue commission, pp. 15, $31-37$. 
phone and express companies upon their gross receipts from business "originating and terminating in this State," at the uniform rate of three per cent. Insurance and guarantee companies likewise were to be taxed three per cent of their premiums. The taxes collected were to be "in lieu of all -other State and local," and were to be paid into the State treasury for the use of the State.* There were no material changes advocated in the taxation of railroads with the exception that "for the purpose of assisting the executive council to more fully determine the actual value of the property of railroads" more detailed information was required of their officers in their annual reports with regard to their capital stock, operating expenses and their earnings. $\dagger$

One member of the commission, Col. Charles A. Clark of Cedar Rapids, urged the commission to recommend the taxation of railroads upon the basis of their net earnings. The writer has before him a manuscript copy of the bill proposed by Col. Clark in which capitalization of net earnings was the method of arriving at the valuation. Where a road extended outside the State he would have pursued the "unit" plan of assessment. Col. Clark, however, did not file his views as a minority report.

The commission did not make these recommendations in their formal report and give a resume of their reasons for urging their adoption, but simply. incorporated them in a draft of a law which they submitted along with the report. Their proposed law met with decided and successful opposition; but the debates made clear not only the need of a thoroughgoing reform in the principles and procedure of taxation, but also the need for a general overhauling of the statutes and a code commission was authorized to revise and recodify all the laws. $\neq$ The code commission in their report and "proposed revision," made in 1896 , included nearly all

* See report of revenue commission, pp. 47-50.

† Ibid, pp. 50-53.

₹ See chapter 115, laws 1894 . 
of the recommendations of the revenue commission, which were enacted into law at the extra session of the assembly in 1897.*

The method proposed for the assessment of general busi. ness corporations aroused the chief opposition. Assess. ment upon market value of capital stock, and solely through the corporations, was considered a "radical" departure from the traditional practice of the State. Among the many measures considered, those relating to the taxation of loan and trust companies and building and loan associations elicited vigorous discussion. At that session the policy of discriminating between United States and foreign insurance companies was adopted. Another measure proposed at that session was that offered by Senator Thomas A. Cheshire of Des Moines, proposing to tax express, telegraph and telephone companies, palace, dining, sleeping and chair car companies upon the market value of their stock and bonds less the value of any realty taxed locally. Where their lines or operations extended beyond the State they were to be assessed as units and that proportion of the entire valuation taken for assessment that the mileage in Iowa bore to the entire mileage of the systems. The bill reproduced the Indiana law. $t$ It failed to pass in the senate, but was introduced in the house and passed; the senate, however, would not concur.

Notwithstanding the changes wrought in the methods of corporate taxation by the recodification of 1897 , public discussion of the subject did not lessen, but increased. This was due chiefly to three causes: (1) Litigation involving the taxation of insurance companies; (2) Agitation for the taxation of corporations controlling communication and trans. portation upon the market value of their stock and bonds; and, (3) Controversies over the assessment of railroads.

\footnotetext{
* See report of code commission, 1896, pp. 48-50, and proposed revision, title VII, sections 19-25; also code, 1897, sections 1323-46.

† See Senate Journal, extra session, 1897, pp: 519, 550.
} 
Copyright of Annals of Iowa is the property of State of Iowa, by \& through the State Historical Society of Iowa and its content may not be copied or emailed to multiple sites or posted to a listserv without the copyright holder's express written permission. However, users may print, download, or email articles for individual use. 